\title{
Comet Assay and Its Use for Evaluating Oxidative DNA Damage in Some Pathological States
}

\author{
M. KUCHAŘOVÁ ${ }^{1,3}$, M. HRONEK ${ }^{2,3}$, K. RYBÁKOVÁ ${ }^{2,3}$, Z. ZADÁK $^{3}$, R. ŠTĚTINA ${ }^{3}$, \\ V. JOSKOVÁ ${ }^{2,3}$, A. PATKOVÁ ${ }^{2,3}$ \\ ${ }^{1}$ Department of Biophysics and Physical Chemistry, Faculty of Pharmacy in Hradec Králové, \\ Charles University, Czech Republic, ${ }^{2}$ Department of Biological and Medical Sciences, Faculty of \\ Pharmacy in Hradec Králové, Charles University, Czech Republic, ${ }^{3}$ Department of Research and \\ Development, University Hospital Hradec Králové, Czech Republic
}

Received March 5, 2018

Accepted August 27, 2018

Epub Ahead of Print October 23, 2018

\section{Summary}

The comet assay, or single-cell gel electrophoresis (SCGE), is a sensitive, rapid, relatively simple and inexpensive method for detecting DNA strand breaks in individual cells. It is used in a broad variety of applications and as a tool to investigate DNA damage and repair. The sensitivity and specificity of the assay are greatly enhanced if the DNA incubated with an enzyme, which recognizes a specific kind of DNA damage. This damage induced by oxidative stress plays a pivotal role in many diseases and in aging. This article is a critical review of the possible application of the comet assay in some pathological states in clinical practice. Most of the studies relate to evaluating the response of an organism to chemotherapy or radiotherapy with statistically significant evidence of DNA damage in patients. Other useful applications have been demonstrated for patients with heart or neurodegenerative diseases. Only a few studies have been published on the use of this method in critically ill patients, although its use would be appropriate. There are also other scenarios where the comet assay could prove to be very useful in the future, such as in predicting the likelihood of certain pathological conditions.

\section{Key words}

Oxidative stress • Comet assay • Clinical practice • ROS • DNA oxidation lesion

\section{Corresponding author}

M. Hronek, Faculty of Pharmacy, The Educational and Research
Center of Charles University, Zborovska 2089, 50003 Hradec Kralove, Czech Republic. Fax: +420 495518 002. E-mail: hronek@faf.cuni.cz

\section{Introduction}

Various methods are used to detect DNA damage in mammalian cells in laboratory practice. The comet assay is a method suitable for this use since it is relatively simple and requires only a few cells, and results can be obtained within a matter of hours. The degree of damage is determined in peripheral blood lymphocytes (PBL) which can be easily collected in a relatively non-invasive way. The precision of the comet assay is not as great as that of chromatographic methods, but it seems to be much more accurate at estimating low level damage. It has a range of detection that is limited by the structural organization of the DNA (Collins 2009). One limitation of this method is the requirement of a viable single-cell suspension. If a sample contains predominantly necrotic or apoptotic cells, accurate information about specific lesions such as strand breaks or base damage cannot be obtained. Therefore it is necessary to minimize additional DNA breaks (Olive and Banáth 2006). The versatility of the applications of this method indicates its utility in addressing a wide range of issues in biology, medicine and toxicology.

One of the most important applications of comet 
assay is the detection of oxidative damage of DNA. Oxidative damage to biomolecules is commonly believed to contribute to, or even to cause, aging. It is not surprising that oxidative damage to DNA, is generally regarded as a significant contributory cause of human diseases. Studies have also been carried out regarding the relationship between the level of DNA damage and the influence of the nutrition, vitamin supplementation and consumption of various kinds of "beneficial" food, and some of them examined whether such diets confer any real protective effect on DNA (Fikrová et al. 2011, Herrero-Barbudo et al. 2013, Bub et al. 2013). Faust et al. (2004) reviewed 45 alkaline comet assay studies with the objective of monitoring human exposure to genotoxic agents resulting from occupation, drug treatment, disease and environmental pollution. They compared the oxidative damage detected of the comet assay with other cytogenetic data, such as the frequency of micronuclei, chromosomal aberrations or sister chromatid exchange. Results show remarkable concordance between comet assay and other classical cytogenetic assay data (Faust et al. 2004). Because of its favorable properties, the comet assay has become a heavily used method in laboratory practice. Evidence for this is the article by Neri et al. (2015) that created a bibliometric study about worldwide interest in the comet assay. They collected articles from the period between 1990 and 2013 using the PubMed website. The geographic and temporal distribution of all publications, the distribution of impact factors by country and the mostused keywords were measured. The results indicated that the number of papers increased from 8 in the triennium 1990-1992 up to 1137 in the 2002-2004 period, and then doubled again from 2011 to 2013. Most papers using the comet assay as a biomarker have been published in genetic and toxicology journals, with emphasis placed on environmental and occupational disciplines (Neri et al. 2015).

Oxidative stress has been studied for several decades with the help of various methods, and more increasingly so recently using comet assay. However, the potential of the comet assay has still not been sufficiently explored or exploited. Thus, the main aim of this critical review was to collect knowledge about this assay, which has turned out to be another promising method that can be applied in clinical practice in some pathologies.

\section{Oxidative stress}

Oxidative stress is associated with many human diseases. It is defined as the predominance of reactive oxygen or nitrogen species over the antioxidant protection of tissues. Normally, these processes are in balance. The source of endogenous reactive oxygen species (ROS) contributing to specific DNA oxidation damage is the result of normal cellular metabolism and they are detected in normal tissue (Cooke et al. 2003); however, they may also be a product of pathological processes. ROS are chemically very active and react with biomolecules other than nucleic acid, also including polyunsaturated fatty acids in membrane lipids and essential proteins (Lambeth 2007). The most important site of origin of ROS in cells is in the mitochondria, where their production is a consequence of aerobic metabolism. Mitochondrial ATP production occurs through the flow of electrons that are passed along a series of molecular complexes in the electron transport system. The result of this transport is proton transition across the inner mitochondrial membrane producing a large mitochondrial membrane potential. The energy released by the protons re-entering the mitochondrial matrix is used to produce ATP. This final electron acceptor is molecular oxygen, which is reduced to water. During this process, single electrons sometimes escape and result in a single-electron reduction of molecular oxygen to form a superoxide anion $\left(\mathrm{O}_{2}{ }^{-}\right)$. It is estimated that as much as $1 \%$ of all oxygen consumed may result in the formation of ROS, such as superoxide anions (Farris et al. 2005). ROS may also be generated by certain enzyme activities, they are released from phagocytic cells meant to destroy cells infected with viruses or bacteria. They also originate in metabolic processes as the $\beta$-oxidation of fatty acids in peroxisomes, by the metabolism of arginine, during the biotransformation of xenobiotics in microsomes by redox mechanisms with cytochrome P450. In addition to these endogenous sources of ROS, there are also numerous environmental sources, notably radiation, air pollution, tobacco smoke and a wide range of chemicals (Loft et al. 2008).

Normally, excessive ROS are controlled and removed from cells by superoxide dismutase, catalase, glutathione peroxidase and by low molecular weight antioxidants such as vitamin $\mathrm{C}, \mathrm{E}$, glutathione and uric acid. Oxidative stress occurs in situations where the production and destruction processes of reactive oxygen species are imbalanced. It is important to recognize that a certain level of damage cannot be avoided. Oxidative stress refers to the state where the balance is impaired, 
either by an excessive production of free radicals or by deficient antioxidant defenses. ROS and antioxidants scavenger balance is important in treating and preventing the damage caused by such stress.

\section{Oxidative damage to DNA}

The integrity of DNA is absolutely crucial for cellular life. However, DNA is constantly exposed to a risk of being damaged. It is estimated that each cell under normal conditions is the target of several thousand attacks on its DNA every day (Olive 2009). After DNA is damaged various methods of cell response can be invoked, amongst them the immediate replacement of the DNA using DNA repair mechanisms, tolerance to the damage or cell death. The DNA damage response is a hierarchical process that is executed through a series of steps. DNA lesions are detected by sensor proteins that recognize either the lesions themselves or chromatin alterations that may follow the DNA damage. Transducers are brought into action to convey the damage signal to downstream effectors. It is this relay system from transducers to effectors that enables a single DNA lesion to modulate numerous pathways. The transducers might also be involved in the assembly of DNA-repair complexes at the sites of DNA damage (Barzilai and Yamamoto 2004).

\section{Measuring DNA oxidation lesions}

There are many methods which can detect DNA damage. Some older methods are no longer commonly used (e.g. sedimentation or alkaline elution) as a consequence of the continuous development of better new methodologies for determining specific DNA damage. Oxidative damage to DNA in cells and tissues can be measured by gas-liquid chromatography and mass spectrometry, high performance liquid chromatography (HPLC) with electrochemical detection or MS/MS (tandem MS) detection, immunoassays, ${ }^{32} \mathrm{P}$-postlabelling and cytometry. The basic protocol of determining DNA damage and repair is single-cell gel electrophoresis (Bub et al. 2013, ESCODD 2003).

\section{Comet assay}

The method was first introduced in 1984 by Ostling and Johanson (1984). It was a combination of cell lysis followed by electrophoresis, both at neutral $\mathrm{pH}$. For better visualization, the DNA was stained with fluorescent acridine orange, which allowed for the detection of the emitted radiation by a photometer. On the microscope slide, an image resembling a comet in the sky, with a distinguishable head containing intact DNA and a tail containing relaxed DNA loops was observed. The amount of DNA released from the head depends on the quantity of acting mutagen. This original neutral method appeared to be suitable for detecting of the double strand breaks (DSB). Singh et al. (1988) published the alkaline version of the method. Both groups of authors employed ionizing radiation (inducing predominantly single strand breaks - SSB) and the dose responses were almost identical, indicating that both neutral and alkaline versions were detecting both SSB and DSB. Methodology used by these authors was likely to be ineffective in removing all protein. This method gradually has become a popular way of detecting a variety of types of DNA damage in individual cells. It is versatile, quick, relatively simple to perform and sensitive. Its greatest advantage is probably the scope of its application. It can be used in a range of scenarios from investigating the physicochemical behaviour of DNA, through studies of cellular responses to DNA damage, to biomonitoring human populations (Collins et al. 1997a). Breaks are detected at the individual cell level, and so the prime requirement is a suspension of single cells, in as near a pristine state as possible. The assay is most commonly applied to cultured mammalian cells, peripheral blood mononuclear (PBMN) cells or disaggregated tissues. Individual cells are first embedded in agarose gel, and are then lysed and subjected to electrophoresis at high $\mathrm{pH}$. DNA migrates out of the cells. DNA containing breaks is drawn towards the anode, forming a comet-like shape resembling an astronomical body, visualized by fluorescence microscopy (Collins 2014). The basis for this is that loops containing a break lose their supercoiling and become free to extend towards the anode. Various stains have been used to visualize comets. Ethidium bromide and DAPI (4',6-diamidino-2-phenylindole) are the most commonly employed fluorochromes. The scoring of comets to evaluate the extent of the DNA damage can be done in several ways. Probably the most precise is the image analysis, with a camera linked to a computer with appropriate software. Comet images are selected by the operator. Automated systems, which search for comets and carry out the analysis with minimal human intervention are also available. The software gives a number of parameters, from which the most important are the comet tail length and \% DNA in tail. Tail length 
seems the most sensitive parameter, which may be useful when very low levels of damage are present. However, at higher number of DNA breaks, the tail does not increase its length anymore, which is given just by the length of relaxed loops, but only the intensity of the tail fluorescence increases as more and more loops are relaxed. In contrast to tail length, the $\%$ tail DNA is linearly related to break frequency and covers the widest range of damage.

Tail moment has been used by many authors which includes both tail length and tail intensity in a single value. Tail moment is the product of $\%$ tail DNA and tail length. It seems rather counterproductive, because linearly dependent parameter is multiplied by non-linear one, which may make the dose-response curve deviate from linearity. Also, cells from different tissues or different species can differ substantially in tail length. Thus, since tail length is a factor in calculating tail moment, similar amounts of damage can give rise to different values of tail moment. Therefore, \% DNA in tail should be preferred as the parameter of choice. However, in spite of the advantages of $\%$ tail DNA mentioned above, the tail moment is widely used.

Another widely used way of scoring comets is a classifying comets by visual inspection. In this case, comets are divided into five categories: 0 representing undamaged cells (comets with no tails) and categories 1-4 representing increasing relative tail intensities estimated by eye. Summing the scores (0-4) of 100 comets gives an overall score of between 0 and 400 arbitrary units, the samples are processed in duplicates usually. Visual inspection is quite respectable and scoring by an experienced operator tends to be faster than image analysis with computer image analysis (Collins 2008).

With modifications, the comet assay has become the most popular method for measuring DNA damage of various types. Attempts to standardization of the SCGE methodology was carried out by a group of researchers within interlaboratory collaboration. The results of this study demonstrate good data reproducibility (ESCODD 2005). Yet the comet analysis remains more or less non-standard and non-standardized method (Collins 2008).

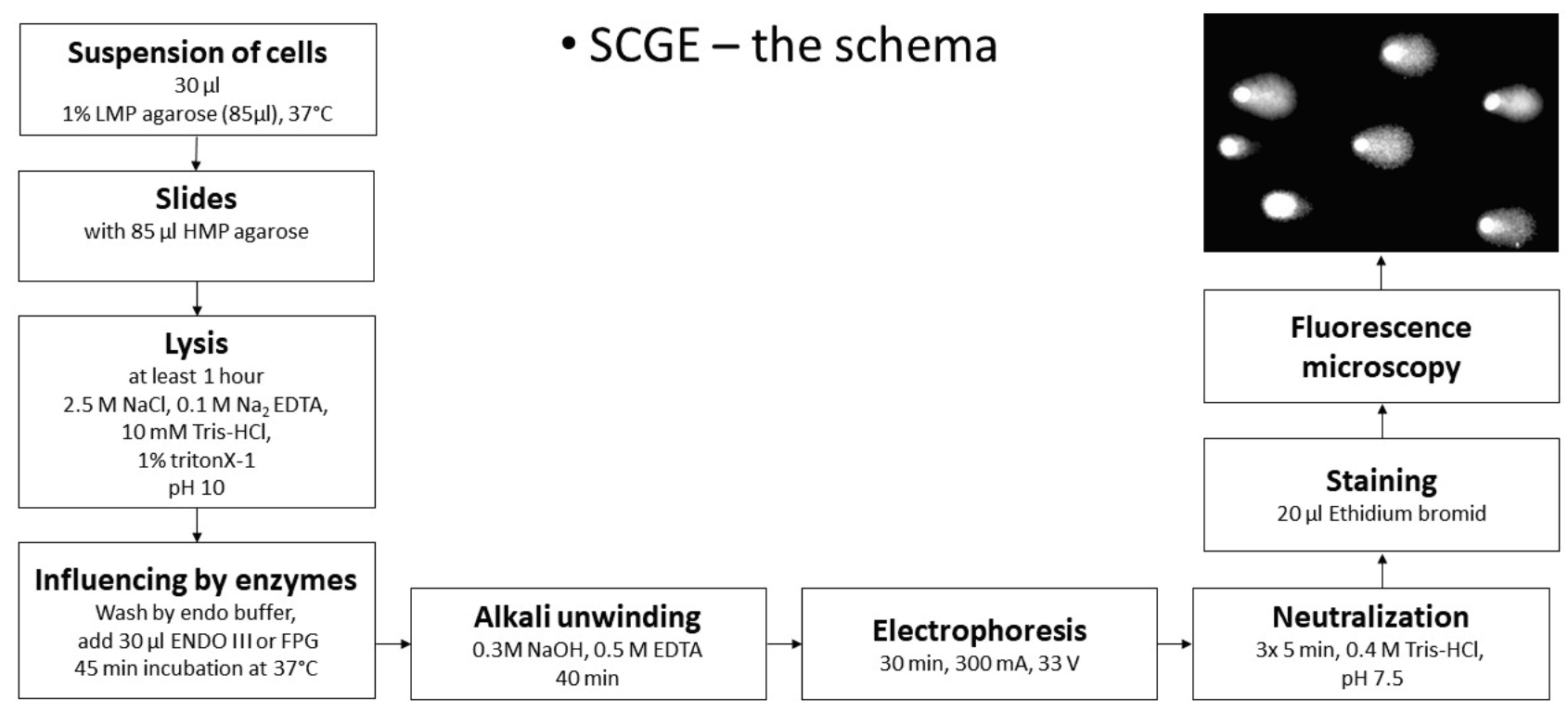

Fig. 1. SCGE - single-cell gel electrophoresis; LMP agarose - low melting point agarose; HMP agarose - high melting point agarose; $\mathrm{Na}_{2}$ EDTA - disodium ethylenediaminetetraacetate dihydrate; ENDO III - endonuclease III; FGP - formamidopyrimidine DNA glycosylase; EDTA - ethylenediaminetetraacetic acid; Tris - tris(hydroxymethyl)aminoethane.

\section{Modification of the comet assay}

The Ostling and Johanson (1984) procedure was not widely adopted. Especially interesting was the importance of $\mathrm{pH}$ during electrophoresis. A few years later, two research groups independently developed procedures involving treatment at high $\mathrm{pH}$. In 1988, Singh et al. found that a significant increase in $\mathrm{pH}$ during electrophoresis $(>13)$ causes the increased release of supercoiled DNA allowing for a highly sensitive detection of SSB in the structure. In another variant of the procedure chosen in 1990 by Olive et al. for measuring cell sensitivity to radiation, the $\mathrm{pH}$ of the electrophoretic solution was adjusted to neutral or slightly alkaline values (Olive et al. 1990). In both approaches, it was observed 
that although the use of alkali makes the comet tails more pronounced and extends the useful range of damage that can be detected, it does not increase the sensitivity (Collins 2004a). However, SSB are quickly repaired, and are not regarded as a significant lethal or mutagenic lesion. Many genotoxic agents do not directly induce strand breaks (Lambeth 2007, Piperakis 2009).

Measuring DNA strand breaks provides limited information, because the standard alkaline comet assay detects strand breaks and alkali-labile sites. A more specific indicator of an oxidative attack is the presence of oxidized purines or pyrimidines. The basic comet assay was modified to detect these by introducing an incubation of the nucleoids with bacterial DNA repair enzymes. These enzymes introduce breaks at sites where DNA damage has occurred. The enzymes combine a specific glycosylase activity, removing the damaged base and creating an apurinic/apyrimidinic (AP) site, and an AP lysate which converts the AP sites to a break. Endonuclease III (Endo III) is an enzyme that helps to eliminate oxidized pyrimidines by base excision repair and in the comet assay, it is used for determining the presence of oxidized pyrimidines (Collins et al. 1993), while formamidopyrimidine-DNA-glycosylase (FPG) acts on oxidized purines. Relative to other DNA nucleobases, the oxidation of guanine occurs most readily due to its low oxidation potential. There are a number of oxidized guanine $(\mathrm{G})$ products of which 8-oxo-7,8dihydroguanine (8-oxoG) or its deoxynucleoside 8-oxo7,8-dihydrodeoxyguanosine (8-oxoGuo) are the most common. Published estimates of the concentration of 8-oxoG/8-oxoGuo in DNA in normal human cells vary over a range of three orders of magnitude. Problem of analysis by chromatographic methods which determine 8-oxoGuo, is adventitious oxidation of $\mathrm{G}$ during sample preparation. FPG - based methods, which recognize 8-oxoG, seem to be less prone to the artefact of additional oxidation and gives much lower values (Neeley and Essigmann 2006, Collins et al. 1997b, Collins et al. 2004b, Tchou et al. 1994).

After incubation with the enzymes, there is an increase in the \% tail DNA compared with incubation with a buffer alone. The enzyme-modified comet assay is widely used, particularly to determine the background levels of oxidized bases in lymphocytes (PBMN cells) (Farris et al. 2005, Collins et al. 1996). Because circulating lymphocytes are comprised of a heterogeneous mixture of various subpopulations that differ in age, cell cycle status and function, it would be expected that DNA damage could not affect all of them equally.

A simple modification allows for the measurement of DNA repair. Charles et al. (2012) used the comet assay to measure the influence on DNA repair kinetics of different flavonoids at the highest non-toxic concentration. The flavonoids have the capacity to modulate DNA repair and this ability was tested (Charles et al. 2012). Similar studies were also carried out by other teams (Azqueta et al. 2014, Silva et al. 2009, Slyskova et al. 2014). The comet assay is therefore a very suitable methodology for evaluating DNA repair.

\section{The clinical use of comet assay}

Over the last two decades, there has been significant interest in oxidative stress and its role in cellular dysfunction and the pathophysiology of many diseases. It could be that a little bit of oxidative stress is good for us. Immune reactions depend on ROS with a cell signaling role in many biological systems. ROS induce programmed cell death or necrosis, induce or suppress the expression of many genes and activate cell signaling cascades (Hancock et al. 2001). However, increased damage, including base oxidation, is likely to increase the risk of cancer, and the comet assay is a useful investigative tool in this area. Because ROS can damage almost any molecule in the body, they have been investigated as a mechanism of injury in many diseases. But it is not clear whether oxidative stress is a cause or a consequence of these diseases (Collins et al. 2014, Oldham and Bowen 1998, Dandona et al. 1996, Fearon and Faux 2009). Many studies have successfully demonstrated how the comet assay can be applied to analyze cells derived from a variety of different human tissues. This type of information would prove particularly relevant in the diagnosis, prognosis and treatment of many types of diseases (McKenna et al. 2008).

Comet assay and oxidative damage in critically ill patients

Critical illness, such as sepsis, polytrauma and adult respiratory distress syndrome can drastically increase the production of ROS/RNS and lead to oxidative stress. Sources of oxidative stress include activation of the phagocytic cells of the immune system, the production of nitric oxide by the vascular endothelium, the release of iron, copper ions and metalloproteins and vascular damage. Critically ill patients have reduced plasma and intracellular levels of 
antioxidants and free-electron scavengers or cofactors, and decreased activity of the enzymatic system involved in ROS detoxification. They show an increase in lipid peroxides, malondialdehyde and xanthine oxidase activity. Conversely, they present reduced levels of $\alpha$-tocopherol, selenium, $\beta$-carotene, lycopene and ascorbic acid (Crimi et al. 2006). Abilés et al. (2006) evaluated the relationship between oxidative stress in critically ill patients and antioxidant vitamin intake and the severity of illness. They used spectrophotometry and observed the total antioxidant capacity and levels of lipid peroxide, carbonyl group, total protein, bilirubin and uric acid in plasma at two different points in time: at intensive care unit (ICU) admission and on day seven. Dietary records were maintained and compliance with the recommended dietary allowance (RDA) of antioxidant vitamins (C and E) was assessed. They found that between admission and day seven in the ICU, the lipid peroxide and carbonyl group levels significantly increased. This growth was associated with a decreased antioxidant capacity and a greater deterioration of the Sequential Organ Failure Assessment score. There was significantly greater worsening in oxidative stress parameters in patients who received antioxidant vitamins at below $66 \%$ of the RDA than in those who received antioxidant vitamin intake from $66 \%$ to $100 \%$ of the RDA. Administering antioxidants at $>66 \%$ of the RDA reduced the risk for worsening oxidative stress by $94 \%$ regardless of any changes in the severity of illness (Abilés et al. 2006). Goode et al. (1995) also found that antioxidant vitamin concentrations were significantly lower in patients with septic shock and secondary organ dysfunction than the reference range obtained from a comparable group of healthy controls. All patients had markedly reduced circulating concentrations of tocopherol, retinol and the carotenoids beta-carotene and lycopene (Goode et al. 1995).

There are very few literature references addressing the use of comet assay for determining DNA oxidation damage in critically ill patients, although the technique would be very suitable. It has been used for example by Zhanataev et al. (2010), who studied DNA damage and cell death in 22 patients with severe multiple trauma, with measurements taken after admission (day 0 ) and on days 3, 5, 7 and 15 during their stay in ICU. The mean value of tail DNA percentage in blood cells from healthy controls was $6.1 \pm 2.2 \%$. They found that trauma patients had high DNA damage at admission $(10.6 \pm 5.9 \%$ DNA in tail; $p<0.01)$, which further increased to a maximum on day $5(14.2 \pm 4.2 \%$ DNA in tail; $p<0.01$ ). On day 15 , the degree of DNA damage remained significantly elevated versus the controls $(6.1 \pm 2.2 \%$ vs. $10.3 \pm 2.4 \%$ DNA in tail; $p<0.01)$ (Zhanataev et al. 2010). The team of Natália Carvalho (2010) determined whether the DNA damage detected using the comet assay helps in the diagnosis of neonatal sepsis. According to their results, there were no significant differences in data between cases and controls. (Carvalho et al. 2010). Roth et al. (2004) assessed the antioxidant status in critically ill patients. They noted that the comet analysis would be an appropriate method for assessing range DNA lesions (Roth et al. 2004).

Comet assay and oxidative damage in cardiovascular diseases

Cardiovascular disease (CVD) is the most common cause of mortality in the Western world. It is multifactorial and involves a complex interaction between lifestyle and fixed causative factors. It may be classified as coronary heart disease, cerebrovascular disease and peripheral vascular disease. The initiating step is endothelial damage. This damage leads to the formation of atherosclerotic lesions, which can occlude small blood vessels and disrupt blood flow. This leads to acute manifestations such as myocardial infarction and stroke, in which tissue oxygen and nutrient supply are severely compromised (Fearon and Faux 2009). Cellular oxidative stress is intrinsic to the formation of lesions. Evidence attesting to the association of DNA damage with cardiovascular disease has been obtained from in vitro cell culture models, and from analysis of blood samples. Amongst the more pertinent risk factors with respect to in vitro effects on cardiovascular cells is hyperglycemia. The association between diabetes and cardiovascular complications has resulted in thorough investigations into the effects of high levels of glucose on cardiovascular cells. This effect has been studied in microvascular endothelial cells (MVEC) and human umbilical vein endothelial cells (HUVEC). Malik and Herbert (2012) have suggested that the mechanism of glucose-induced oxidative stress is an increase in the generation of mitochondrial ROS. Exposure of MVEC to a high glucose concentration $(25 \mathrm{mM}, 24 \mathrm{~h})$ resulted in increase in heme-oxygenase-1, a stress response protein, and elevated 8-oxoG (Malik and Herbert 2012, Farhangkhoee et al. 2005). Quagliaro et al. (2005) found that exposing cells intermittently to high glucose concentrations results in a more severe effect on the cells 
than constant high glucose. Their results show that after 14 days of exposure of HUVEC to intermittent high $(20 \mathrm{mM})$ and normal $(5 \mathrm{mM})$ glucose levels, there was a 2-fold increase in 8-oxoG levels compared to constant exposure to high glucose (Quagliaro et al. 2005). Kliemann et al. (2012) evaluated the association between the risk of developing CVD and DNA damage levels in children and adolescents. DNA damage levels were assessed by the comet assay. They used a standard protocol for the comet assay based on silver staining and visual scoring. The level of DNA damage was correlated positively with various CVD risk parameters (BMI, body fat, total cholesterol and triglycerides). The findings suggest that, compared to those with low CVD risk, high CVD risk children and adolescents have the highest levels of primary DNA damage, but they did not differ in terms of permanent DNA damage. CVD risk factors such as adiposity, hypertension, total cholesterol, LDL and triglycerides correlated with primary DNA damage level (Kliemann et al. 2012). The link between angiotensin II (Ang II), which is crucial in regulating of the cardiovascular system, and DNA oxidation, has been investigated by Mazza et al (2003). Ang II increased DNA damage in human dermal MVEC, as measured by the comet assay. DNA damage was significantly increased in dermal MVEC treated with $0.19 \mu \mathrm{M}$ Ang II for $16 \mathrm{~h}$; however the extent of DNA damage was significantly decreased in cells pre-treated with the hemeoxygenase-1 inducer Tin(II) chloride $\left(\mathrm{SnCl}_{2}\right)$. Since the overexpression of heme-oxygenase-1, a stress response protein, has been associated with protection against oxidative stress, these data indicate the DNA damage to be ROS-dependent (Mazza et al. 2003). Vidya et al. (2014) conducted a case-control study on 40 children with congenital heart disease and compared the level of DNA damage with age- and sex-matched healthy children. They used the alkaline version of the comet assay and evaluated comet tail length, total comet length and the $\%$ of DNA in the head. The parametric unpaired T-test was used to estimate the differences between the case and control groups at a significance threshold of $p<0.05$. Regarding the details of DNA damage, the total comet length among the cases $(68.1 \pm 14.7 \mu \mathrm{m})$ was observed to be significantly higher $(p<0.001)$ than in the controls $(30.3 \pm 5.2 \mu \mathrm{m})$. Similarly, the $\%$ of DNA in the head and comet tail length were also found to be significantly higher $(p<0.001)$ in the cases compared to the controls (Vidya et al. 2014). The authors of this work, as well as some others, use more assay descriptors of
DNA damage, but it does not have to bring more information about range of this damage and improve a quality of the work. Botto with coworkers (2002) used the comet assay to measure oxidative damage to DNA from 13 patients with angiographically documented coronary artery disease (CAD) and 11 age - and sex matched controls. Mean values of DNA strand breaks $(p<0.0001)$, oxidized pyrimidines $(p<0.0001)$ and altered purines $(p=0.0009)$ were significantly higher in CAD patients than in the control group. With the number of influenced vessels oxidized purines increases and positively correlated with the extent of CAD measured by dint of the number of the coronary lesions $(p=0.003)$. Also found that the diabetic patients have higher levels of oxidized pyrimidines $(p=0.013)$, while patients with dyslipidemia have elevated altered purines compared with normal patients $(p=0.03)$. Data indicate that the extent of oxidative damage DNA in CAD patients correlates with the severity of disease (Botto et al. 2002).

Comet assay and oxidation damage in neurodegenerative diseases

Neurodegenerative conditions, Alzheimer's disease (AD), Huntington's disease and Parkinson's disease (PD) all have oxidative stress implicated in their pathophysiology, although there are publications that say otherwise (Alam et al. 2000). Oxidative stress to the central nervous system predominantly manifests as lipid peroxidation, which may promote the formation of additional ROS, and enhancement of protein and DNA oxidation.

Kadioglu et al. (2004) studied the deleterious consequences of excessive oxidation and the role of ROS in $\mathrm{AD}$ patients. They observed the levels of oxidative damage in PBL of $24 \mathrm{AD}$ and of 21 age-matched controls by the comet assay applied to freshly isolated blood samples with oxidative lesion-specific DNA repair endonucleases. It was demonstrated a significant elevation $(p<0.01)$ of basal levels of SSB and alkali-labile sites in the PBL of AD patients (16.8 \pm 4.6$)$ in comparison with the controls (13.0 \pm 2.7$)$. The inclusion of Endo III and FPG in the comet assay revealed extra sites of damage in both patients and controls. In the case of Endo III, a significant elevation $(p<0.0001)$ in the mean total comet score was found in AD patients (36.1 \pm 6.9$)$

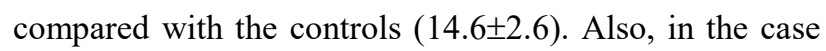
of treatment with FPG, a significant elevation $(p<0.0001)$ in the mean total comet score was found in AD patients (31.3 \pm 7.3$)$ as compared with the controls $(14.4 \pm 2.5)$ 
(Kadioglu et al. 2004). A similar study was performed by Morocz et al. (2002), who observed 27 late onset sporadic $\mathrm{AD}$ patients and 12 age-matched control subjects. The alkaline comet assay showed a non-significant elevation of basal levels of SSB and alkali-labile sites in the PBL of AD patients, compared with the controls. The authors explain it so there is no defect in the essential components of repair kinetics of $\mathrm{AD}$ lymphocytes and controls. To assess the basal level of oxidation damage of purines in patients, the nuclei of lymphocytes were treated with FPG. A significant elevation in the percentage of tail DNA was found in AD patients compared with the controls $(p<0.05)$. Lymphocytes were also treated with Endo III and with a combination of both FPG and Endo III. The Endo III treatment revealed a non-significantly higher level of oxidized pyrimidines in lymphocytes from AD patients compared to the controls. Application of the combined enzyme treatment detected a significant elevation in the amount of total oxidized bases in AD subjects versus the controls $(p<0.05)$. The level of repair capacity in PBL was also determined. Cells were exposed to $\mathrm{H}_{2} \mathrm{O}_{2}$ stress and processed for the comet assay after one hour. After this period, the amount of remaining SSB and alkalilabile sites did not differ significantly between lymphocytes from $\mathrm{AD}$ subjects and those from the controls, reflecting a similar effectiveness of repair (Morocz et al. 2002). Migliore at al. (2002) observed 20 patients with de novo sporadic PD and 16 control subjects matched for age, sex and smoking habits. They underwent a cytogenetic analysis using a micronucleus assay. The comet assay was performed in 15 of the 20 patients with PD and 14 of the 16 control subjects. A triple increase in the levels of SSB was found in patients with PD compared with the control subjects (9.6 $\pm 4.3 \mu \mathrm{m}$ versus $3.3 \pm 2.3 \mu \mathrm{m} ; p<0.001)$. A positive correlation between the percentage of centromerenegative micronuclei and the level of SSB was observed in PD patients. A modified version of the comet assay was used to detect oxidized purines and pyrimidines. The levels of SSB, due to oxidized purines, were higher in the group of patients with PD compared with the control $(22.4 \pm 3.8 \mu \mathrm{m} \quad$ versus $\quad 17.3 \pm 6.2 \mu \mathrm{m} ; \quad p<0.052)$. No significant differences in oxidized pyrimidines were observed between the two groups (Migliore et al. 2002). Also, Petrozzi et al. (2001) performed the comet assay in 19 PD patients and 16 healthy controls. Compared with the controls, the PD patients showed about a three-fold increase in the levels of SSB, expressed as the length of comet tail DNA $(p<0.001)$, and significant differences in the distribution of oxidized purine bases between the two groups ( $p<0.05)$ were observed (Petrozzi et al. 2001).

\section{Comet assay and oxidative damage in cancerous diseases}

It has been established that oxidative mechanisms play a role in the initiation, promotion and progression stages of carcinogenesis. The cancer risk increases with the fourth power of age and is associated with an accumulation of DNA damage. DNA damage and repair are the underlying molecular events driving the initiation and progression of cancer. Therefore many studies have used the comet assay to investigate DNA damage and repair characteristics. Its potential has been examined as a tool for predicting an individual's tumour sensitivity to radiation and to various chemotherapeutic drugs, as well as for its usefulness in assessing oxidative stress within tumours. Patients generally are of two types: those receiving radiotherapy and those receiving chemotherapy (McKenna et al. 2008, Collins 2009).

A study by Gamulin (2007) included patients diagnosed with different solid tumours who were receiving radiotherapy. Blood samples were collected before (samples I) and after receiving the first dose of radiotherapy (samples II), in the middle of the radiotherapy cycle (samples III) and after the last dose of radiotherapy (samples IV), and the level of DNA damage was determined using the alkaline comet assay on PBL. They monitored two parameters - DNA migration (tail length; $\mu \mathrm{m}$ ) and tail moment. The results revealed interindividual differences in pre-therapy DNA damage in cancer patients. The individual DNA migration \pm standard error of the mean was in range from $15.73 \pm 0.19 \mu \mathrm{m}$ to $37.85 \pm 3.12 \mu \mathrm{m}$. For the whole studied group, mean tail length of $22.54 \pm 5.58 \mu \mathrm{m}$ was recorded. Corresponding tail moment values were in range $13.11 \pm 0.19$ to $34.11 \pm 2.97$. The cause of differences in pre-therapy DNA damage levels may be explained by different life-style factors, as well as different sensitivity to diagnostic treatment prior to operation and radiotherapy. The assessment of the two comet parameters in samples II confirmed a strong positive response to therapy $(p<0.05$, t-test for dependent samples). Although the inter-individual differences among patients obviously reflect the impact of the radiation doses applied, they also indicated different susceptibility and genome sensitivity. The range of tail lengths was from $18.6 \pm 0.6 \mu \mathrm{m}$ to $60.3 \pm 2.2 \mu \mathrm{m}$. Corresponding tail moment values were in range 
$15.7 \pm 0.6$ to $54.8 \pm 2.1$. Specific patterns of DNA damage were recorded in blood samples analysed in the middle of the radiotherapy cycle (samples III). In the majority of the patients a decrease in DNA damage as compared to sample II was observed. The range of tail lengths was from $16.4 \pm 0.2 \mu \mathrm{m}$ to $44.0 \pm 1.7 \mu \mathrm{m}$, and the range of the tail moment was from $13.9 \pm 0.2$ to $40.0 \pm 1.6$. Results from blood samples collected after administration (samples IV) indicate the possibility of an adaptive response. They did not greatly differ and were lower than before the therapy. The results indicated the persistence of post-irradiation damage, which is a strong determinant of cancer risk (Gamulin et al. 2007). Another study by the same team also found that oropharyngeal cancer patients had relatively high levels of primary DNA damage in their PBL even before therapy (Gamulin et al. 2008).

Table 1. Summary of Comet Assay results in critically ill patients, cardiovascular and neurodegenerative diseases.

\begin{tabular}{|c|c|c|}
\hline & Comet Assay study & Results of studies \\
\hline \multirow[t]{2}{*}{$\begin{array}{l}\text { Critically ill } \\
\text { patients }\end{array}$} & Severe polytrauma & $\begin{array}{l}\text { High DNA damage in polytrauma patients, maximal difference at day } 5 \text { after } \\
\text { admission ( } 22 \text { trauma patients and } 12 \text { controls) (Goode } \text { et al. 1995) }\end{array}$ \\
\hline & Neonatal sepsis & $\begin{array}{l}\text { No statistical difference between septic and control group (24 sepsis patients } \\
\text { and } 24 \text { controls) (Zhanataev et al. 2010) }\end{array}$ \\
\hline \multirow[t]{3}{*}{$\begin{array}{l}\text { Cardiovascular } \\
\text { diseases (CVD) }\end{array}$} & $\begin{array}{l}\text { Children and } \\
\text { adolescent with } \\
\text { high CVD risk }\end{array}$ & $\begin{array}{l}\text { The highest levels of primary DNA damage in person with high CVD risk, } \\
\text { but no difference in permanent DNA damage (Quagliaro et al. 2005) }\end{array}$ \\
\hline & $\begin{array}{l}\text { Congenital heart } \\
\text { disease in children }\end{array}$ & $\begin{array}{c}\text { Significantly higher the total comet length, \% DNA in head and comet tail } \\
\text { length in cases ( } 40 \text { subjects of various congenital heart disease) and controls } \\
\text { (40 subject), no statistical significance at \% DNA in tail and head diameter } \\
\text { between groups (Mazza et al. } 2003 \text { ) }\end{array}$ \\
\hline & $\begin{array}{l}\text { Coronary artery } \\
\text { disease (CAD) }\end{array}$ & $\begin{array}{l}\text { Values of DNA strand breaks, oxidized pyrimidines and purines were } \\
\text { significantly higher in CAD patients (13 subjects) than in control group } \\
\qquad(11 \text { subjects) (Vidya } \text { et al. } 2014)\end{array}$ \\
\hline \multirow[t]{4}{*}{$\begin{array}{l}\text { Neurodegenerative } \\
\text { diseases }\end{array}$} & $\begin{array}{l}\text { Alzheimer's } \\
\text { disease (AD) }\end{array}$ & $\begin{array}{l}\text { Significant elevation of oxidative damage in peripheral PBL of patients } \\
\text { ( } 24 \text { subjects) than in control group ( } 21 \text { subjects) (Kadioglu et al. } 2004 \text { ) }\end{array}$ \\
\hline & $\begin{array}{l}\mathrm{AD}+\text { repair } \\
\text { capacity in } \mathrm{PBL}\end{array}$ & $\begin{array}{l}\text { Insignificant elevation of DNA SSB between AD patients ( } 27 \text { subjects) and } \\
\text { control (12 subjects), elevations of oxidized purines in nuclear DNA of PBL } \\
\text { in AD patients (at basal level and after oxidative stress), diminished repair of } \\
\text { oxidized purine in AD (Morocz et al. } 2002 \text { ) }\end{array}$ \\
\hline & $\begin{array}{l}\text { Parkinson's } \\
\text { disease (PD) }\end{array}$ & $\begin{array}{l}\text { An increase in the incidence of SSB and oxidized purine bases in patients } \\
\text { with PD (20 subjects) compared with controls (16 subjects) } \\
\text { (Migliore et al. 2002) }\end{array}$ \\
\hline & PD & $\begin{array}{l}\text { A significant increase in SSB levels and oxidized purine base levels in PD } \\
\text { patients (19 subjects) than in control group (16 subjects) } \\
\text { (Petrozzi et al. 2001) }\end{array}$ \\
\hline
\end{tabular}

We carried out a study involving 20 patients with stage 4 non-small cell lung cancer, together with 10 age-corresponding healthy controls. Blood samples from patients who had undergone chemotherapy for the first time were collected before starting the $1^{\text {st }}$ cycle of chemotherapy, before starting the $3^{\text {rd }}$ cycle of chemotherapy, and 3 weeks after the $4^{\text {th }}$ final cycle. They received platinum-based derivatives in a combined therapy. Patients were in the last stage of cancer and chemotherapy was indicated as palliative. The DNA damage was estimated by the comet assay and was expressed as the percentage of tail DNA. In the healthy 
controls, the percentage of tail DNA was $6.7 \pm 1.2$. In cancer patients, the percentage of tail DNA was 11.8 \pm 3.9 . The results therefore show that changes occur in the amount of SSB and DNA crosslinks during the course of chemotherapy. The mean value of the $\%$ of tail DNA for patients increased throughout chemotherapy. In the cancer patient group, a high inter-individual variability was found. To the determination of the incidence of DNA crosslinks, which can be caused by cisplatin, the modification of the comet assay protocol was used. It was found highest incidence of DNA crosslinks immediately or 1 day after chemotherapy. Cisplatin can react with DNA in several ways, the most common is the reaction with guanine leading to the formation of intrastrand crosslinks. Seven days after chemotherapy the level of crosslinks gradually decreases and returns to prechemotherapy levels (Fikrova et al. 2014).

Table 2. Summary of Comet Assay results in cancerous diseases.

The dynamics of the repair of radiotherapy-induced DNA

Cancerous diseases

lesions in patients with solid tumors of the head and neck, prostate, uterus, lungs, breast, brains and testes

Oropharyngeal cancer (OC) before, during and after radiotherapy

Non-small cell lung cancer

(NSCLC) treated with platinum derivatives

Breast cancer (BC): alkaline and neutral comet assay

BC - combined adjuvant
chemotherapy

$\mathrm{BC}$

Non-small cell lung carcinoma undergoing chemotherapy

BC, Hodgkin's syndrome
Inter-individual differences between patients with different types of tumors (10 subjects) of tail length and moment in pre-therapy DNA damage, confirmed a strong positive response to the therapy (Gamulin et al. 2007)

High levels of primary DNA damage in PBL even before therapy in OC patients (10 subjects), DNA damage increased with progression of the radiation cycle and the delivered dose (Gamulin et al. 2008)

Non-significant higher percentage tail DNA in cancer patients (20 NSCLC patients) than in controls (10 subjects), the DNA base excision repair activity significantly higher than in cancer patients, the same level of the activity of DNA nucleotide excision repair (Fikrova et al. 2014)

A greater percentage and higher degree (tail moment) of DNA strand breaks of PBL in BC patients (40 patients in clinical stage III) than controls (60 subjects) (Sanchez et al. 2004)

Higher percentage of both SSB and DSB before treatment cancer patients (41 subjects) compared to the healthy women (60 subjects), after $2^{\text {nd }}$ chemotherapy cycle the number of DNA-damaged PBLs increased significantly and persisted until the end of treatment

(Sánchez-Suárez et al. 2008)

Increased background levels of DNA damage in PBL in BC patients (30 subjects) than healthy women (30 subjects) (Kopjar et al. 2006)

A significant reduction in percentage tail DNA in all patients ( 5 subjects) during the first and third cycle of the chemotherapy

(Fikrova et al. 2013)

No significant difference between experimental groups (17 subjects with breast cancer with over-reactions to radiotherapy, 9 subjects with Hodgkin's disease with over-reactions to radiotherapy, 22 ill subjects with breast cancer or Hodgkin's disease with normal reactions to radiotherapy, 24 healthy subjects) after exposure to 2 and 5 Gy. High inter-individual variation was observed (Alapetite et al. 1999) 
Alkaline comet assays have been used in studies on breast and colon cancer patients receiving chemotherapy. Sanchez et al. (2004) investigated this issue. They observed 40 breast untreated cancer patients in clinical stage III with no cancer family history in comparison with 60 age-matched healthy subjects as controls. PBL were processed by an alkaline and a neutral comet assay. The purpose of the study was to investigate whether PBL of untreated sporadic breast cancer patients exhibit an elevated number of DNA strand breaks. The results showed that PBL of cancer patients carry a higher number of DNA strand breaks than those of the controls. In the controls, DNA breaks found with the alkaline method (showing both SSB and DSB) were found in $18 \pm 4.67 \%$ of PBL. In cancer patients this value was higher $24.08 \pm 4.96 \%$. In the controls, the tail moment was $6.23 \pm 1.44$, while for breast cancer patients, the tail moment was $11.73 \pm 2.40$ (Sanchez at al. 2004). In another study, Sánchez-Suárez (2008) studied 41 patients with advanced breast cancer before and after chemotherapy, together with 60 healthy female subjects. Breast cancer patients before treatment had higher background levels of DNA beaks as compared to healthy women. During treatment, a significant increase in DNA damage was observed after the second cycle and persisted until the end of treatment. There was no correlation between DNA damage and the response to chemotherapy (Sánchez-Suárez et al. 2008). Also, other working group studied the relationship between the response to chemotherapeutics and DNA damage for different cancers (Apostolou et al. 2014, Kopjar et al. 2006, Dorie et al. 1999, Fikrová et al.2013).

Alapetite et al. (1999) investigated whether a defect in DNA repair capacity might be involved in hypersensitive phenotypes. They compared lymphocytes irradiated in vitro at 5 Gy from 17 breast cancer and 9 Hodgkin's disease patients who had developed severe reactions to radiotherapy, with 22 patients with "average" reactions and 24 healthy blood donors. Using the alkaline comet assay, they analysed the responses as a function of time. A difference was observed at 30 and $60 \mathrm{~min}$ after exposure between all groups. Their results suggest that impairment in DNA strand break processing may be associated with an individual risk of major toxicity from radiation therapy. The basal level of DNA damage in non-irradiated PBL did not differ significantly between groups. In lymphocytes in which DNA damage was detected immediately after in vitro exposure to $5 \mathrm{~Gy}$, no significant difference was observed between them.
A high inter-individual variation was observed. Measurements of DNA strand break induction after exposure to 2 Gy led to the same conclusion (Alapetite et al. 1999). Thus, the comet assay appears to be useful for documenting the DNA repair phenotype in cancer patients.

\section{Conclusions}

The comet assay is a very useful tool for measuring DNA damage in numerous varied pathological and physiological conditions. For measuring DNA strand breaks, the comet assay is already recognized as being among the most sensitive methods available and has the further advantages of speed and simplicity. Since observations are at the single cell level, it is relatively free of artefacts. The comet assay has been described in numerous articles as being a valuable tool in monitoring the effects of dietary antioxidants and environmental exposure to genotoxins on DNA damage and repair. On the other hand, its application in clinical practice is used relatively less frequently, though has been demonstrated as being useful for evaluating various pathophysiological factors and therapeutic interventions on DNA damage and repair in cardiovascular, cancer and specific neurodegenerative diseases. However, being non-specific, it cannot be used to diagnose these diseases. Application in polytrauma and septic patients is not yet entirely clear due to a lack of information. Another possible use for the comet assay could be for evaluating the as yet poorlyunderstood influence of anaesthesia and surgery on the level of DNA damage.

\section{Conflict of Interest}

There is no conflict of interest.

\section{Acknowledgements}

All authors have read and approved the final manuscript. The authors are grateful to Ian McColl, $\mathrm{MD}, \mathrm{PhD}$, for his assistance with the manuscript. There is no financial conflict of interest. This work was not supported by any sponsors. The Faculty of Pharmacy (SVV/2017/260417), PROGRES Q42 and MH CZ - DRO (UHHK, 00179906) are gratefully acknowledged. 


\section{References}

ABILÉS J, PÉREZ DE LA CRUZ A, CASTANO J, RODRÍGUEZ-ELVIRA M, AGUAYO E, MORENO-TORRES R, LLOPIS J, ARANDA P, ARGÜELLES S, AYALA A, MACHADO DE LA QUINTANA A, PLANELLS EM: Oxidative stress is increased in critically ill patients according to antioxidant vitamins intake, independent of severity: a cohort study. Crit Care 10: R146, 2006.

ALAM ZI, HALLIWELL B, JENNER P: No evidence for increased oxidative damage to lipids, proteins, or DNA in Huntington's disease. J Neurochem 75: 840-846, 2000.

ALAPETITE C, THIRION P, DE LA ROCHEFORDIERE A, COSSET JM, MOUSTACCHI E: Analysis by alkaline comet assay of cancer patients with severe reactions to radiotherapy: defective rejoining of radioinduced DNA strand breaks in lymphocytes of breast cancer patients. Int J Cancer 83: 83-90, 1999.

APOSTOLOU P, TOLOUDI M, MIMIKAKOU G, VLACHOU I, CHATZIIOANNOU M, PAPASOTIRIOU I: Use of the comet assay technique for quick and reliable prediction of in vitro response to chemotherapeutics in breast and colon cancer. J Biol Res (Thessalon) 21: 14, 2014.

AZQUETA A, SLYSKOVA J, LANGIE SAS, O’NEIL GAIVĂO I, COLLINS A: Comet assay to measure DNA repair: approach and applications. Front Genet 5: 1-8, 2014.

BARZILAI A, YAMAMOTO KI: DNA damage responses to oxidative stress. DNA repair 3: 1109-1115, 2004.

BOTTO N, MASETTI S, PETROZZI L, VASSALLE C, MANFREDI S, BIAGINI A, ANDREASSI MG: Elevated levels of oxidative DNA damage in patients with coronary artery disease. Coron Artery Dis 13: 269-274, 2002.

BUB A, WATZL B, BLOCKHAUS M, BRIVIBAA K, LIEGIBEL U, MÜLLER H, POOL-ZOBEL BL, RECHKEMMER G: Fruit juice consumption modulates antioxidative status, immune status and DNA damage. J Nutr Biochem 14: 90-98, 2013.

CARVALHO NC, DE SOUZA RL, DAL-PIZZOL F, ANDRADE VM: Comet assay in neonatal sepsis. Indian J Pediatr 77: 875-877, 2010.

CHARLES C, CHEMAIS M, STÉVIGNY C, DUBOIS J, NACHERGAEL A, DUEZ P: Measurement of the influence of flavonoids on DNA repair kinetics using the comet assay. Food Chem 135: 2974-2981, 2012.

COLLINS AR, DUTHIE SJ, DOBSON VL: Direct enzymic detection of endogenous oxidative base damage in human lymphocyte DNA. Carcinogenesis 14: 1733-1735, 1993.

COLLINS AR, DUŠINSKÁ M, GEDICK CM, ŠTĚTINA R: Oxidative damage to DNA: do we have a reliable biomarker? Environ Health Perspect 104: 465-469, 1996.

COLLINS AR, DOBSON VL, DUŠINSKÁ M, KENNEDY G, ŠTĚTINA R: The comet assay: what can it really tell us? Mutat Res 375: 183-193, 1997a.

COLLINS A, CADET J, EPE B, GEDIK C: Problems in the measurement of 8-oxoguanine in human DNA. Report of a workshop, DNA oxidation, held in Aberdeen, UK, 19-21 January, 1997. Carcinogenesis 18: 1833-1836, 1997b.

COLLINS AR: The comet assay for DNA damage and repair. Mol Biotechnol 26: 249-261, 2004a.

COLLINS AR, CADET J, MÖLLER L, POULSEN HE, VINA J: Are we sure we know how to measure 8-oxo-7,7dihydroguanine in DNA from human cells? Arch Biochem Biophys 423: 57-65, 2004b.

COLLINS AR, OSCOZ AA, BRUNBORG G, GAIVĂO I, GIOVANNELLI L, KRUSZEWSKI M, SMITH CC, ŠTĚTINA R: The comet assay: topical issues. Mutagen 23: 143-151, 2008.

COLLINS AR: Investigating oxidative DNA damage and its repair using the comet assay. Mutat Res 681: 24-32, 2009.

COLLINS AR: Measuring oxidative damage to DNA and its repair with the comet assay. Biochim Biophys Acta 1840: 794-800, 2014a.

COLLINS A, KOPPEN G, VALDIGLESIAS V, DUSINSKA M, KRUSZEWSKI M, MØLLER P, ROJAS E, DHAWAN A, BENZIE I, COSKUN E, MORETTI M, SPEIT G, BONASSI S: The comet assay as a tool for human biomonitoring studies: ComNet project. Mutat Res 759: 27-39, 2014b.

COOKE MS, EVANS MD, DIZDAROGLU M, LUNEC J: Oxidative DNA damage: mechanisms, mutation, and disease. FASEB J 17: 1195-1214, 2003.

CRIMI E, SICA V, WILLIAMS-INGARRO S, ZHANG H, SLUTSKY AS, IGNARRO LJ, NAPOLI C: The role of oxidative stress in adult critical care. Free Radic Biol Med 40: 398-406, 2006. 
DANDONA P, THUSU K, COOK S, SNYDER B, MAKOWSKI J, ARMSTRONG D, NICORETA T: Oxidative damage to DNA in diabetes mellitus. Lancet 437: 444-445, 1996.

DORIE MJ, KOVACS MS, GABALSKI EC, ADAM M, LE QT, BLOCH DA, PINTO HA, TERRIS DJ, BROWN JM: DNA damage measured by the comet assay in head and neck cancer patients treated with tirapazamine. Neoplasia 1: 461-467, 1999.

ESCODD, GEDIK CM, COLLINS A: Establishing the background level of base oxidation in human lymphocyte DNA: Results of an interlaboratory validation study. FASEB $J$ 19: 82-84, 2005.

EUROPEAN STANDARDS COMMITTEE ON OXIDATIVE DNA DAMAGE (ESCODD): Measurement of DNA oxidation in human cells by chromatographic and enzymic methods. Free Radic Biol Med 34: 1089-1099, 2003.

FARHANGKHOEE H, KHAN ZA, BARBIN Y, CHAKRABARTI S: Glucose-induced up-regulation of CD36 mediates oxidative stress and microvascular endothelial cell dysfunction. Diabetologia 183: 1341-1348, 2005.

FARISS MW, CHAN CB, PATEL M, VAN HOUTEN B, ORRENIUS S: Role of mitochondria in toxic oxidative stress. Mol Interv 5: 94-111, 2005.

FAUST F, KASSIE F, KNASMÜLLER S, BOEDECKER RH, MANN M, MERSCH-SUNDERMANN V: The use of alkaline comet assay with lymphocytes in human biomonitoring studies. Mutat Res 566: 209-229, 2004.

FEARON IM, FAUX SP: Oxidative stress and cardiovascular disease: Novel tools give (free) radical insight. J Mol Cell Car 47: 372-381, 2009.

FIKROVÁ P, ŠTĚTINA R, HRONEK M, HYŠPLER R, TICHÁ A, ZADÁK Z: Application of the comet assay method in clinical studies. Wien Klin Wochenschr 123: 1-7, 2011.

FIKROVA P, STETINA R, HRNCIARIK M, REHACEK, JOST P, HRONEK M, ZADAK Z: Detection of DNA crosslinks in peripheral lymphocytes isolated from patients treated with platinum derivates using modified comet assay. Neoplasma 60: 411-416, 2013.

FIKROVA P, STETINA R, HRNCIARIK M, HRNCIARIKOVA D, HRONEK M, ZADAK Z: DNA crosslinks, DNA damage and repair in peripheral blood lymphocytes of non-small cell lung cancer patients treated with platinum derivatives. Oncol Rep 31: 391-396, 2014.

GAMULIN M, GARAJ-VRHOVAC V, KOPJAR N: Evaluation of DNA damage in radiotherapy - treated cancer patients using the alakline comet assay. Coll Antropol 31: 837-845, 2007.

GAMULIN M, KOPJAR N, GRGIĆ N, RAMIĆ S, BIŠOF V, GARAS-VRHOVAC V: Genome damage in oropharyngeal cancer patients treated by radiotherapy. Croat Med J 49: 515-527, 2008.

GOODE HF, COWLEY HC, WALKER BE, HOWDLE PD, WEBSTER NR: Decreased antioxidant status and lipid peroxidation in patients with septic shock and secondary organ dysfunction. Crit Care Med 23: 646-651, 1995.

HANCOCK JT, DESIKAN R, NEIL SJ: Role of reactive oxygen species in cell signalling pathways. Biochem Soc Trans 29: 345-350, 2001.

HERRERO-BARBUDO C, SOLDEVILLA B, PÉREZ-SACRISTÁN B, BLANCO-NAVARRO I, HERRERA M, GRANADO-LORENCIO F, DOMÍNGUEZ G: Modulation of DNA-induced damage and repair capacity in humans after dietary intervention with lutein-enriched fermented milk. PLoS One 8: 1-6, 2013.

KADIOGLU E, SARDAS S, ASLAN S, ISIK E, KARAKAYA AE: Detection of oxidative DNA damage in lymphocytes of patients with Alzheimer's disease. Biomarkers 9: 203-209, 2004.

KLIEMANN M, PRÁ D, MÜLLER LL, HERMES L, HORTA JA, RECKZIEGEL MB, BURGOS MS, MALUF SW, FRANKE SIR, DA SILVA J: DNA damage in children and adolescents with cardiovascular disease risk factors. An Acad Bras Cienc 84: 833-840, 2012.

KOPJAR N, MILAS I, GARAJ-VRHOVAC V, GAMULIN M: Alkaline comet assay study with breast cancer patients: evaluation of baseline and chemotherapy-induced DNA damage in non-target cells. Clin Exp Med 6: 177-190, 2006.

LAMBETH JD: Nox enzymes, ROS, and chronic disease: An example of antagonistic pleiotropy. Free Radic Biol Med 43: 332-347, 2007.

LOFT S, DANIELSEN PH, MIKKELSEN L, RISOM L, FORCHHAMMER L, MØLLER P: Biomarkers of oxidative damage to DNA and repair. Biochem Soc Trans 36: 1071-1076, 2008. 
MALIK Q, HERBERT KE: Oxidative and non-oxidative DNA damage and cardiovascular disease. Free Radic Res 46: 554-564, 2012.

MAZZA F, GOODMAN A, LOMBARDO G, VANELLA A, ABRAHAM NG: Heme oxygenase -1 gene expression attenuates angiotensin II-mediated DNA damage in endothelial cells. Exp Biol Med 228: 576-583, 2003.

MCKENNA DJ, MCKEOWN SR, MCKELVEY-MARTIN VJ: Potential use of the comet assay in the clinical management of cancer. Mutagenesis 23: 183-190, 2008.

MIGLIORE L, PETROZZI L, LUCETTI C, GAMBACCINI G, BERNARDINI S, SCARPATO R, TRIPPI F, BARALE R, FRENZILLI G, RODILA V, BONUCCELLI U: Oxidative damage and cytogenetic analysisi in leukocytes of Parkinson's disease patients. Neurology 58: 1809-1815, 2002.

MOROCZ M, KALMAN J, JUHASZ A, SINKÓ I, MCGLYNN AP, DOWNES SC, JANKA Z, RASKÓ I:. Elevated levels of oxidative DNA damage in lymphocytes from patients with Alzheimer's disease. Neurobiol Aging 23: 47-53, 2002.

NEELEY WL, ESSIGMANN JM: Mechanism of formation, genotoxicity, and mutation of guanine oxidation products. Chem Res Toxicol 19: 491-505, 2006.

NERI M, MILAZZO D, UGOLINI D, MILIC M, CAMPOLONGO A, PASQUALETTI P, BONASSI S: Worldwide interest in the comet assay: a bibliometric study. Mutagenesis 30: 155-163, 2015.

OLDHAM KM, BOWEN PE: Oxidative stress in critical care: Is antioxidant supplementation beneficial? $J$ Am Diet Assoc 98: 1001-1008, 1998.

OLIVE PL, BANÁTH JP, DURAND RE: Heterogeneity in radiation-induced DNA damage and repair in tumor and normal cells measured using the "comet" assay. Radiat Res 122: 86-94, 1990.

OLIVE PL, BANÁTH JP: The comet assay: a method to measure DNA damage in individual cells. Nat Protoc 1: 23-29, 2006.

OLIVE PL: Impact of the comet assay in radiobiology. Mutat Res 681: 13-23, 2009.

OSTLING O, JOHANSON KL: Microelectrophoretic study of radiation-induced DNA damages in individual mammalian cells. Biochem Biophys Res Commun 123: 291-298, 1984.

PETROZZI L, LUCETTI C, GAMBACCINI G, BERNARDINI S, DEL DOTTO P, MIGLIORE L, SCARPATO R, BONUCCELLI U: Cytogenetic analysis oxidative damage in lymphocytes of Parkinson's disease patients. Neurol Sci 22: 83-84, 2001.

PIPERAKIS SM: Comet assay: A brief history. Cell Biol Toxicol 25: 1-3, 2009.

QUAGLIARO L, PICONI L, ASSALONI R, DA ROS R, MAIER A, ZUODAR G, CERIELLO A: Intermittent high glucose enhances ICAM-1, VCAM-1 and E-selectin expression in human umbilical vein endothelial cells in culture: The distinct role of protein kinase $\mathrm{C}$ and mitochondrial superoxide production. Atherosclerosis $\mathbf{1 8 3}$ : 259-267, 2005.

ROTH E, MAMHART N, WESSNER B: Assessing the antioxidative status in critically ill patients. Curr Opin Clin Nutr Metab Care 7: 161-168, 2004.

SANCHEZ P, PEÑARROJA R, GALLEGOS F, BRAVO JL, ROJAS E, BENÍTEZ-BRIBIESCA L: DNA damage in peripheral lymphocytes of untreated breast cancer patients. Arch Med Res 35: 480-483, 2004.

SÁNCHEZ-SUÁREZ P, OSTROSKY-WEGMAN P, GALLEGOS-HERNÁNDEZ F, PEÑARROJA-FLORES R, TOLEDO-GARCÍA J, BRAVO JL, ROJAS DEL CASTILLO E, BENÍTEZ-BRIBIESCA L: DNA damage in peripheral blood lymphocytes in patients during combined chemotherapy for breast cancer. Mutat Res $\mathbf{6 4 0}$ : $8-15,2008$.

SILVA JP, GOMES AC, PROENÇA F, COUTINHO OP: Novel nitrogen compounds enhance protection and repair of oxidative DNA damage in a neuronal cell model: Comparison with quercetin. Chem Biol Interact 181: 328-337, 2009.

SINGH NP, MCCOY MT, TICE RR, SCHNEIDER EL: A simple technique for quantitation of low levels of DNA damage in individual cells. Exp Cell Res 175: 184-191, 1988.

SLYSKOVA J, LANGIE SA, COLLINS AR, VODICKA P: Functional evaluation of DNA repair in human biopsies and their relation to other cellular biomarkers. Front Genet 5: 1-10, 2014. 
TCHOU J, BODEPUDI V, SHIBUTANI S, ANTOSHECHKIN I, MILLER J, GROLLMAN AP, JOHNSON F: Substrate specificity of Fpg protein. Recognition and cleavage of oxidatively damaged DNA. J Biol Chem 269: 15318-15324, 1994.

VIDYA G, SUMA HY, VISHU BHAT B, CHAND P, RAMACHANDRA RAO K, HARICHANDRAKUMAR KT: Estimation of DNA damage through comet assay in children with congenital heart disease - case-control study. Curr Pediatr Res 18: 1-4, 2014.

ZHANATAEV AK, MOROZ VV, DURNEV AD, MURAVYEVA MY, RESHETNYAK VI: DNA damage and cell death assessment in patients with severe multiple trauma using comet assay. Health 2: 412-417, 2010. 